\title{
Pääkirjoitus:
}

\section{Emme ole koskaan olleet totuudenjälkeisiä}

\author{
Ville-Pekka Sorsa, päätoimittaja
}

Oxfordin maineikkaat sanakirjat valitsivat vuonna 2016 vuoden sanaksi totuudenjälkeisyyden (post-truth). Sanakirjamääritelmän mukaan "totuudenjälkeisyys" viittaa tai liittyy olosuhteisiin, joissa objektiiviset faktat ovat vähemmän vaikutusvaltaisia julkisen mielipiteen määrittelyssä kuin vetoaminen tunteisiin tai omakohtaisiin uskomuksiin. Vuoden sanaksi valintaa motivoi termin esiintymistaajuuden nopea kasvaminen vuoden aikana sekä yleinen huolestuneisuus demokratian tilasta. Jälkimmäistä motivoivat erityisesti Ison-Britannian kansanäänestys Euroopan unionin jäsenyydestä, jonka voittaneen Leave-kampanjan ohjelma paljastui olemattomaksi.

Totuudenjälkeisyys on monella tapaa ongelmallinen termi. Ensinnäkin on vaikea kuvitella, että koskaan olisi eletty totuudenjälkeisyyttä "edeltävää" eli totuuden aikaa. Totuutta voidaan toki pitää tärkeimpänä valistusajan ja sitä seuranneen modernisaatioprojektin ideaalina. Olisi silti naiivia olettaa, että objektiiviset faktat olisivat koskaan tosiasiallisesti vaikuttaneet julkiseen mielipiteeseen enemmän kuin ihmisten tunteet tai uskomukset. Yhteiskunta ei ole insinöörin rakentama kone, jonka julkinen mielipide -funktiossa vallitseva kognitiivinen tai emotionaalinen informaatio olisi ratkaiseva ohjaava voima. Yhteiskunta on perustaltaan kontingentti valtakamppailujen ja organisoidun toiminnan tuote. Objektiiviset faktat ovat julkisesti vaikutusvaltaisia vain, jos ne yhdistyvät organisoituun vallankäyttöön. Sama kuitenkin pätee myös emootioihin, omakohtaisiin uskomuksiin ja julkiseen mielipiteeseen. Vallankäytössä on vedottava emootioihin ja tietoon, niin julkiseen kuin yksityiseenkin, kuten kaikkiin mahdollisiin ihmisten mielenmaisemaan ja toimintaan vaikuttaviin tekijöihin, jotta minkäänlaisiin valta-asemiin koskaan päästäisiin.

Puhe totuudenjälkeisyydestä voidaan tulkita jonkinlaiseksi yritykseksi nostaa tieteen asemaa nyky-yhteiskunnassa. Tiedettä voidaan toki ymmärtää 
organisoituna totuuden tavoitteluna. Totuuden tavoitteluun ei kuitenkaan kuulu pyrkimys tuottaa "lopullisia" tai kiistattomia faktoja julkiseen keskusteluun, vaan loputon kritiikki ja keskustelu maailman luonteesta ja sitä ohjaavista voimista eri aikoina ja eri olosuhteissa. Suurin osa tieteellisestä keskustelusta tapahtuu tieteen instituutioiden, kuten yliopistojen, vertaisarvioitujen julkaisujen ja konferenssien puitteissa. Julkisuudessa toimiessaan tieteentekijät eivät ole näiden instituutioiden määrittämässä asemassa, vaan pitkälti samassa tilanteessa kuin muutkin. Tiede on luultavasti aina operoinut "totuudenjälkeisessä" tai pikemminkin ei-totuudellisessa yhteiskunnassa. Tieteentekijät eivät ole koskaan olleet julkisen mielipiteen määrittelyssä sellaisessa asemassa, josta käsin he olisivat voineet esittää objektiivisia faktoja jollain tavalla suojatusti ja automaattista arvovaltaa nauttien.

Myös tiede itsessään on ollut aina jossain määrin "totuudenjälkeistä". Tiedettä eivät ensisijaisesti ohjaa objektiiviset faktat, vaan niiden tuotanto ja tulkinta. Faktat ovat aina riippuvaisia niiden havaitsemisen tavoista, minkä vuoksi materiaaliset ja sosiaaliset teknologiat määrittävät pitkälti sitä, millaisia faktoja kulloinkin on havaittavissa. Esimerkiksi työntekijöiden hyvinvointia koskevat faktat ovat mahdollisia vain sellaisessa yhteiskunnassa, jossa esiintyy jonkinlaista työksi ja työntekijyydeksi hahmotettavaa asiaa, ja jossa voidaan ylipäätään havainnoida kaikkien työntekijöiden toimintaa jollain validilla ja luotettavalla tavalla. Mitkään asiantilat eivät ole objektiivisia faktoja ilman teoriaa, jotka kertovat, mitä asiaa eri faktat koskevat, mistä näkökulmasta katsottuna asiantiloja voidaan pitää relevantteina sekä millaiset määreet ja rajaukset tekevät niistä objektiivisia faktoja.

Objektiiviset faktat sellaisenaan eivät vie tiedettä eteenpäin tai välttämättä edes määrää tieteellistä mielipidettä. Objektiivisten faktojen antama empiirinen evidenssi auttaa lähinnä vahvistamaan tai falsifioimaan teorioita sekä sitä kautta fokusoimaan lupaaviin ja vähemmän lupaaviin teoreettisiin pohdintoihin. Tiede edistyy teoreettisten innovaatioiden eli tulkintojen monipuolistumisen, relevanttien ilmiöiden hahmottamisen ja oman näkökulman rajallisuuden tiedostamisen edistymisen avulla. Tämän vuoksi filosofia on yhtä tärkeä tieteen edistäjä kuin empiirinen tutkimus. Tieteen erikoistumisen aikakaudella teoreetikkojen merkitys on luultavasti kasvanut entisestään tieteen edistymisen suhteen. Tiede instituutiona ei kuitenkaan etene näin suoraviivaisesti. Tästä kertoo vanha viisaus, jonka mukaan tiede etenee hautakivi kerrallaan. 
Tieteen portinvartijoilla on omat käsityksensä relevanteista ilmiöistä, teoreettisista lähestymistavoista ja sopivista tieteellisen toiminnan muodoista. Vain uusien portinvartijoiden valtaanpääsy nostaa uudet teoreettiset näkökulmat ja sitä kautta mahdollisesti eri faktat merkittävään asemaan.

Yhteiskuntatieteissä "totuudenjälkeisyys" on tätäkin monimutkaisempi kysymys. Kuten tämänkin lehden sivulla on moneen kertaan todettu, yhteiskuntatieteet sisältävät aina normatiivisia sitoumuksia, eikä niiden tutkimuskohde ole riippumaton tutkimuksesta. Kuten jo Adam Smith pääteoksessaan Moraalituntojen teoria aikoinaan esitti, ihmistieteiden tutkimuskohteena ovat ihmiset, jotka ovat omaksuneet jonkin teoreettisen ajattelutavan, jotka puolestaan voivat aina saada vaikutteita tieteellisistä teorioista. Yhteiskuntaa koskevia faktoja ei voida tuottaa ilman, että joidenkin ihmisten omakohtaiset uskomukset eroaisivat niistä. Yhteiskunnalliseksi ymmärrettyjä faktoja ei voida myöskään tulkita teoreettisesti ilman, että tultaisiin ottaneeksi tavalla tai toisella kantaa ihmisten omiin tulkintoihin. Eikä tutkimuksessa voida koskaan välttää sitä mahdollisuutta, että tutkimus vaikuttaisi ihmisten käsitykseen yhteiskunnasta. Yhteiskuntatieteellisissä tulkinnoissa on aina jonkinasteisia poliittisia ulottuvuuksia, minkä vuoksi niitä on helppo myös politisoida - niin faktojen, emootioiden kuin omakohtaisten kokemuksienkin pohjalta.

Politiikan tutkijan näkökulmasta totuudenjälkeisyys on ongelmallinen käsite, koska se yksinkertaistaa liiaksi käsitystä politiikasta. Demokraattiseen politiikkaan kuuluu aina loputon kiista yhteiskunnan sopivasta ideologisesta, sosiaalisesta, normatiivisesta ja tiedollisesta perustasta. Ajatus totuudenjälkeisyydestä nostaa helposti sellaisen mielikuvan, että yhteiskuntaa joko pyöritetään faktojen varassa tai ei. Käsitys on tietysti liiallisen naiivi. Kukaan ei voi saada aikaiseksi mitään ilman joidenkin välittömien tosiasioiden tunnustamista. Tämä ei kuitenkaan tarkoita sitä, että kaikki faktat olisivat yhtä relevantteja tai että niistä vedettäisiin vain yhdenlaisia tulkintoja. Politiikan ymmärtämisen kannalta on oleellisempaa ymmärtää, miten faktoja tuotetaan, minkä faktojen varassa yhteiskuntaa ohjataan, millaisille faktojen tulkinnoille annetaan yhteiskunnassa tilaa sekä miten faktat ja niiden tulkinnat yhdistetään muihin poliittisiin kysymyksiin. Demokratian kannalta on tärkeintä antaa 
tilaa moninaisuudelle jokaisen piirteen osalta, mutta huolehtia samalla siitä, että kansalaiset ovat kykeneviä arvioimaan näkemyksiä.

Otetaan esimerkki. Kuten tämän lehden edellisvuoden numeron sivuilla todettiin (ks. Sorsa 2015), julkistalouden kestävyysvaje esitetään usein faktana. Kyseessä on kuitenkin lukemattomien oletusten varaan rakentuvan alkeellisen laskentamallin tuotos, jota tulkitaan talous- ja sosiaalipolitiikassa hyvin yksisuuntaisesti valtionhallinnon omaksuman ideologian varassa. Se on myös pakko tunnustaa faktana, mikäli kotimainen poliittinen toimija haluaa nyt tai tulevaisuudessa toimia valtionvarainministeriön ja sitä kautta koko virallisen julkishallinnon kanssa. Lisäksi tämän faktan tuotanto on istutettu niin syvälle eurooppalaiseen oikeusjärjestykseen, että sen avulla voidaan käyttää teknokraattista valtaa yli eurooppalaisen tai valtiollisten demokratioiden. Kestävyysvajeen tapauksessa haasteena demokratialle ei vaikuttaisi olevan piittaamattomuus faktoista. Päinvastoin, ongelmana on se, että yhdenlaiselle faktantuotannolle ja sen yksisilmäiselle tulkinnalle on onnistuttu haalimaan demokraattisen päätöksenteon ylittävää valtaa.

Rikkaiden maiden demokraattisuuden suhteen on syytä olla huolissaan "totuudenjälkeisyyttä" enemmän tiedontuotannon resurssien heikentämisestä ja poliittisesta ohjauksesta sekä niin kutsutun episteemisen hallinnan muuttumisesta aggressiivisemmaksi. Jälkimmäisellä tarkoitan yhtäältä tiedon tulkinnan vahvempaa diskursiivista ja institutionaalista kontrollia ja toisaalta tiedon käytön sosiaalisten kontrollikeinojen muuttumista tiukemmiksi, esimerkiksi sosiaalisen median kautta tapahtuvin hyökkäyksin julkiseen keskusteluun osallistuvia henkilöitä kohtaan muodossa. Nämä ovat omiaan tukahduttamaan tiedontuotannon moninaisuutta ja "tyhmentämään" päätöksentekoa joka tasolla.

Demokraattisen moninaisuuden ja "vertaisarvioinnin" ylläpito ei ole helppoa. Sekä demokraattinen keskustelu että siinä edistetyn toiminnan toteutus vaatii aina organisoitua toimintaa. Tällä hetkellä demokraattinen keskustelu näyttää antautuvan usein sosiaalisen median lynkkausjoukoille, Donald Trumpin kaltaisille massa-identiteettipolitiikan mestareille sekä talouselämän eliittien intresseille. Pelkkä faktojen toistelu julkisessa keskustelussa ei riitä näille poliittiseksi vastavoimaksi, koska edellä kuvattujen tahojen politiikan lähtökohta on faktojen relevanssin ja tulkintojen kontrolli. Totuudenjälkeisyyden toitottaminen ei taas riitä mobilisointiin demokraattisen eli 
moninaisen ja vertaiskunnioitukseen perustuvan keskustelun ja päätöksenteon edistämiseksi. "Totuudellisuuden" edistäminen voi johtaa yhtä lailla "yhden totuuden” eli äärimmäisen episteemisen hallinnan edistämiseen.

Poliittinen talous -lehden yksi tarkoitus on tuoda esiin politiikan tutkimuksen ja taloustieteen tulkinnallis-teoreettisten viitekehysten moninaisuutta. Tämän numeron kantava teema onkin poliittisen talouden tulkintaerot ja niiden näkyväksi tekeminen.

Jussi Ahokas tarkastelee alkuperäisartikkelissaan John Maynard Keynesin ajamaa talouspolitiikkaa. Ahokkaan mukaan suomalaisen tieteellisen keskustelun käsitys keynesiläisestä talouspolitiikasta ei vastaa Keynesin itsensä ajamaa talouspolitiikkaa. Artikkeli osoittaa, että Keynes itse asiassa vastusti vastasyklistä budjettipolitiikkaa, jota on pidetty kotimaisessa keskustelussa keynesiläisen talouspolitiikan kantavana lähtökohtana. Keynesin ajama talouspoliittinen ohjelma perustui investointien hallintaan täystyöllisyyden saavuttamiseksi historiallisesti spesifeissä sotienjälkeisissä olosuhteissa. Ahokas tiivistää Keynesin talouspoliittisen ohjelma-ajattelun artikkelissaan kymmeneen kantavaan periaatteeseen.

Ahokkaan artikkeli on hyvä esimerkki menneisyyden tulkinnan merkityksestä. Aiempien tutkimusten mukaan Suomessa ei ole koskaan harjoitettu "keynesiläistä" talouspolitiikkaa vastasyklisten budjettien mielessä, minkä vuoksi Keynesin vaikutus kotimaiseen talouspolitiikkaan ja keynesiläisen talouspolitiikan suosio on oletettu vähäiseksi. Suomen sodanjälkeinen talouspolitiikka kuitenkin muistuttaa suurilta osin Keynesin oman talouspoliittisen ohjelman ohjenuoria. Onko kotimainen talouspolitiikka ollut sittenkin keynesiläistä? Mikäli näin on, niin vaikuttiko Keynesin oma talouspoliittinen ohjelma jollakin tavalla myös suomalaiseen talouspolitiikkaan? Ahokas nostaa artikkelissaan kiinnostavan haasteen kotimaisen taloushistorian tutkijoille. Samalla hän huomauttaa, että keynesiläisen politiikan vähäinen suosio ei välttämättä ole johtunut suosion vähäisyydestä, vaan siitä, että tutkimuksessa on tarkasteltu virheellisen talouspoliittisen käsityksen suosiota. 
Lehdessä julkaistaan myös neljän keskustelunavauksen muodostama symposium, toimittanut dosentti Teppo Eskelinen. Symposium rakentuu Wolfgang Streeckin teoksen Ostettua aikaa: Demokraattisen kapitalismin lykätty kriisi (Vastapaino 2015) ja kirjoittajan Suomen-vierailun yhteydessä järjestetyn seminaarin ympärille. Wolfgang Streeck on yksi maailman tunnetuimpia ja viitatuimpia vertailevan poliittisen talouden tutkijoita ja taloussosiologeja. Hän toimi Kölnin Yhteiskuntatutkimuksen Max Planck-instituutin johtajana ja Kölnin yliopiston sosiologian professorina vuosina 1995-2014. Hän on tutkinut erityisesti edistyneiden kapitalististen talouksien institutionaalista muutosta ja teollisuusmaiden työmarkkinasuhteiden kehitystä. Emeritusprofessori Streeck piti vierailuluennot Tampereella ja Helsingissä 1.-2.11.2016. Tampereen 1.11. luennon yhteydessä pidettiin myös kotimaisten tutkijoiden symposium.

Symposiumin muodostavissa keskustelunavauksissa tehdään uudelleentulkintoja Streeckin (2015) keskeisistä teeseistä. Väitöskirjatutkija Jaakko Belt (2016) tiivistää kirjoituksessaan Streeckin teoksen keskeisin annin symposiumin johdannoksi. Kaksi seuraavaa tutkijapuheenvuoroa kritisoivat Streeckin teoreettisia taustaoletuksia ja tulkinnan lähtökohtia. Dosentti Teppo Eskelinen (2016) tarkastelee kriittisesti Streeckin käsityksiä "vakauttajavaltion” historiasta sekä kapitalismin normaali- ja poikkeustiloista. Väitöskirjatutkija Lauri Holappa (2016) puolestaan kritisoi Streeckin käsitystä talouspolitiikan pakoista ja rajoista erityisesti rahapoliittisen suvereniteetin näkökulmasta. Toimittaja Eetu Viren (2016) pohtii symposiumin lopuksi, miksi finansoimisen poliittinen projekti ja Streeckin kuvaama "velkavaltio" hyväksyttiin, sekä esittelee rahan luomisen ja julkisen toimivallan välisen suhteen poliittisia tulkintoja.

Kirsikkana kakun päällä numerosta löytyy Pekka Kuuselan kirja-arvio Ulrich Bröcklingin yrittäjyyssubjektin luontia ja hallintaa tarkastelevasta teoksesta The Entrepreneurial Self. Fabricating a New Type of Subject (Lontoo: Sage, 2016). Kuuselan mukaan Bröcklingin teos syventää ja monipuolistaa erityisesti tulkintoja yrittäjyydestä uusliberaalina valtiollisena projektina. 


\section{Lähteet}

Belt, Jaakko. 2016. Teknokraattinen kulissidemokratia vai kadun vastarinta? Wolfgang Streeckin demokratiapessimismi. Poliittinen talous, 4:1. http://www. poliittinentalous.fi/ojs/index.php/poltal/article/view/52/45 [Luettu 27.12.2016] Eskelinen, Teppo. 2016. Makroselityksistä, vakauttajavaltioista ja kapitalismista. Poliittinen talous, 4:1. http://www.poliittinentalous.fi/ojs/index.php/poltal/ article/view/53/51 [Luettu 27.12.2016]

Holappa, Lauri. 2016. Wolfgang Streeck ja talouspolitiikan pakot. Poliittinen talous, 4:1. http://www.poliittinentalous.fi/ojs/index.php/poltal/article/ view/54/49 [Luettu 27.12.2016]

Sorsa, Ville-Pekka. 2015. Johdatus symposiumiin: kestävän talouden ja vahvan kestävyyden jäljillä. Poliittinen talous, 3:1. 11-27. http://www.poliittinentalous. fi/ojs/index.php/poltal/article/view/40/35 [Luettu 27.12.2016]

Streeck, Wolfgang. 2015. Ostettua aikaa: Demokraattisen kapitalismin lykätty kriisi. Tampere: Vastapaino.

Viren, Eetu. 2016. Kaksi provokatiivista kysymystä rahasta ja politiikasta. Poliittinen talous, 4:1. http://www.poliittinentalous.fi/ojs/index.php/poltal/ article/view/55/50 [Luettu 27.12.2016] 